\title{
PERILAKU KONSUMSI MAKANAN CEPAT SAJI PADA REMAJA DAN DAMPAKNYA BAGI KESEHATAN
}

\section{Fast Food Consumption Behavior in Adolescent and ITS Impact for Health}

\author{
1Icha Pamelia \\ 1Departemen Promosi Kesehatan dan Ilmu Perilaku \\ Fakultas Kesehatan Masyarakat Universitas Airlangga \\ Email : icha.pamelia-2015@fkm.unair.ac.id
}

\begin{abstract}
Adolescent nutritional needs need to be considered because in adolescence there is rapid growth and development. Unhealthy eating habits will affect adolescent nutrition. Unhealthy foods such as fast food are consumed by teenagers. At a time when everything is modern like now, teenagers want everything to be fast, including in choosing food. Fast food is also known to the public as junk food. Junk food is defined as food waste or food that does not have nutrients for the body. Eating junk food is not only in vain, but can also damage health. Fast food comes from western countries which generally have high fat and calorie content. Many factors influence teenagers eating fast food. These factors are discussed based on research articles and book references. Factors that influence consumption of fast food include taste, price, a comfortable place, and peer influence. Fast food can increase the risk of several diseases, such as obesity, diabetes, hypertension, and disorders of blood fat or dyslipidemia. Obesity or obesity is experienced by many children, adolescents, and adults. Obesity occurs because of a changing lifestyle, including eating patterns that often consume fast food. Eating fast food too often does not only cause obesity. However, from obesity experienced by someone, it will increase a person's risk factors for other degenerative diseases, such as high blood pressure, diabetes, cancer, heart disease, and stroke.
\end{abstract}

Keywords: adolescents, fast food, obesity

\begin{abstract}
Abstrak
Kebutuhan gizi remaja perlu diperhatikan karena pada masa remaja terjadi pertumbuhan dan perkembangan yang cepat. Kebiasaan makan yang tidak sehat akan mempengaruhi asupan gizi remaja. Makanan tidak sehat seperti makanan cepat saji banyak dikonsumsi remaja. Pada saat semua serba modern seperti sekarang, remaja menginginkan semuanya serba cepat, termasuk dalam memilih makanan. Makanan cepat saji juga dikenal masyarakat sebagai junk food. Junk food diartikan sebagai makanan sampah atau makanan yang tidak memiliki nutrisi bagi tubuh. Makan makanan junk food tidak hanya sia-sia, tetapi juga dapat merusak kesehatan.Makanan cepat saji berasal dari negara barat yang umumnya memiliki kandungan lemak dan kalori yang tinggi. Banyak faktor yang

${ }^{1}$ Icha Pamela adalah Departemen Promosi Kesehatan dan Ilmu Perilaku Fakultas Kesehatan Masyarakat Universitas Airlangga
\end{abstract}


mempengaruhi remaja mengonsumsi makanan cepat saji. Faktor-faktor tersebut dibahas berdasarkan artikel penelitian maupun referensi buku. Faktor yang mempengaruhi konsumsi makanan cepat saji diantaranya adalah rasa, harga, tempat yang nyaman, maupun pengaruh teman sebaya. Makanan cepat saji dapat meningkatkan risiko beberapa penyakit, seperti obesitas, diabetes, hipertensi, dan gangguan lemak darah atau dislipidemia. Obesitas atau kegemukan banyak dialami oleh anak-anak, remaja, hingga dewasa. Obesitas terjadi karena pola hidup yang berubah, termasuk pola makan yang sering mengonsumsi makanan cepat saji. Makan makanan cepat saji yang terlalu sering tidak hanya menyebabkan obesitas. Namun, dari obesitas yang dialami oleh seseorang, maka akan meningkatkan faktor risiko seseorang untuk menderita penyakit degeneratif lainnya, seperti tekanan darah tinggi, diabetes, kanker, penyakit jantung, dan stroke.

Kata Kunci : remaja, makanan cepat saji, obesitas

\section{PENDAHULUAN}

Remaja adalah orang yang berada pada usia antara 10 hingga 19 tahun $^{32}$. Menurut Peraturan Menteri Kesehatan Nomor 25 Tahun 2014, remaja adalah kelompok usia 10 tahun sampai berusia 18 tahun. Remaja dimulai pada usia 12 tahun dan berakhir sekitar usia 17 atau 18 tahun $^{29}$. Remaja memiliki kebutuhan nutrisi yang spesial dibandingkan kelompok umur lainnya. Hal ini karena pada saat remaja terjadi pertumbuhan yang pesat dan perubahan kematangan fisiologis sehubungan dengan masa pubertas $^{8}$.

Remaja membutuhkan kebutuhan gizi yang berbeda apabila ditinjau dari sisi biologis maupun psikologis. Secara biologis, kebutuhan nutrisi remaja harus seimbang dengan aktivitasnya. Remaja membutuhkan lebih banyak protein, vitamin dan mineral dari setiap energi yang dikonsumsi dibandingkan dengan masa anak-anak. Apabila dipandang dari sisi psikologis, remaja tidak terlalu memperhatikan faktor kesehatan dalam menentukan pilihannya. Namun, remaja lebih memperhatikan faktor lain, seperti orang-orang sekitar, budaya hedonistik, dan lingkungan sosial yang sangat mempengaruhi ${ }^{1}$.
Kebutuhan gizi pada remaja perlu diperhatikan. Hal ini karena kebutuhan nutrisi pada remaja meningkat karena terjadi peningkatan pertumbuhan dan perkembangan. Selain itu, gaya hidup dan kebiasaan makan yang berubah juga akan mempengaruhi asupan gizi remaja. Kelompok usia remaja disibukkan dengan banyaknya aktivitas fisik. Oleh karena itu, kebutuhan kalori, protein, dan mikronutien pada usia remaja perlu diperhatikan ${ }^{1}$.

Makanan merupakan suatu kebutuhan pokok untuk pertumbuhan dan perkembangan, begitu pun bagi remaja. apabila remaja kurang mengonsumsi makanan, baik secara kuantitas maupun kualitas, maka akan menyebabkan gangguan proses metabolisme tubuh, sehingga dapat mengarah pada risiko timbulnya penyakit. Selain itu, apabila remaja mengomsumsi makanan berlebih tanpa diimbangi aktivitas fisik yang cukup, maka remaja akan mengalami gangguan tubuh, seperti berisiko mengalami penyakit degeneratif ${ }^{1}$.

Saat ini, banyak remaja yang menyukai makanan cepat saji atau fast food. Remaja yang memiliki aktivitas sosial yang tinggi, cenderung memperlihatkan interaksi dengan teman 
sebaya. Di kota besar, banyak dijumpai sekelompok remaja yang makan bersama di tempat makan yang menyediakan makanan cepat saji atau fast food. Makanan cepat saji tersebut berasal dari negara barat yang umumnya memiliki kandungan lemak dan kalori yang tinggi. Apabila dikonsumsi dalam jumlah banyak setiap hari, maka dapat menyebabkan obesitas. Obesitas atau kegemukan ini dapat menyebabkan timbulnya masalah gizi lainnya ${ }^{1}$.

Makanan cepat saji atau fast food juga dikenal masyarakat dengan istilah junk food. Secara harfiah, junk food diartikan sebagai makanan sampah atau makanan tidak bergizi. Istilah tersebut berarti menunjukkan makanan-makanan yang dianggap tidak memiliki nilai nutrisi bagi tubuh. Makan makanan junk food tidak hanya sia-sia, tetapi juga dapat merusak kesehatan. Gangguan kesehatan akibat makan makanan junk food seperti obesitas atau kegemukan, diabetes, hipertensi, penyakit jantung koroner, stroke, kanker, dan lain sebagainya ${ }^{27}$.

Berdasarkan penelitian di Bangladesh, siswa yang mengonsumsi makanan cepat saji sebanyak $\geq 2$ hari per minggu berisiko 2,2 kali mengalami obesitas $^{9}$. Selain itu, penelitian lain menunjukkan bahwa 90\% remaja yang mengonsumsi makanan cepat saji, $22,45 \%$ mengalami pre-obesitas dan $9,52 \%$ mengalami obesitas ${ }^{31}$. Sebanyak $54,40 \%$ siswa menyukai makanan cepat saji dan lebih dari $60 \%$ siswa tidak menyadari mengenai fakta bahwa makanan cepat saji adalah makanan yang tidak sehat ${ }^{25}$.

Makanan cepat saji maupun junk food menjadi populer karena penyajian yang cepat, tersedia secara luas, mudah diperoleh, dan memiliki rasa yang enak. Namun, kebiasaan makan dengan mengonsumsi makanan cepat saji ataupun junk food berlebih akan berdampak buruk bagi kesehatan, baik pada anak, remaja, maupun dewasa. Makanan cepat saji dapat meningkatkan risiko beberapa penyakit, seperti obesitas, diabetes, hipertensi, dan gangguan lemak darah atau dislipidemia. Selain itu, makanan cepat saji dalam waktu yang lama juga akan mempengaruhi kesehatan gigi. Makanan cepat saji yang memiliki kandungan gula yang tinggi dapat menyebabkan karies gigi atau gigi berlubang ${ }^{19}$.

Berdasarkan uraian yang telah dijelaskan sebelumnya, maka akan dibahas lebih mendalam mengenai faktorfaktor apa saja yang mempengaruhi perilaku remaja untuk mengonsumsi makanan cepat saji. Selain itu, akan dibahas juga mengenai dampak kesehatan dari kebiasaan mengonsumsi makanan cepat saji.

\section{PEMBAHASAN}

\section{Faktor Yang Mempengaruhi Perilaku Konsumsi Makanan Cepat Saji}

\section{Pengetahuan \\ Pengetahuan \\ dapat}

mempengaruhi perilaku seseorang, termasuk pengetahuan tentang gizi yang dapat mempengaruhi perilaku mengonsumsi makanan. Pengetahuan remaja berhubungan dengan adanya fasilitas informasi, seperti perpustakaan di sekolah, laboratorium komputer dan ruang multimedia untuk mencari informasi terkini. Pengetahuan gizi yang kurang serta menongonsumsi makanan yang tidak bergizi dapat menimbulkan masalah rendahnya zat gizi dalam tubuh ${ }^{14}$.

\section{Pengaruh Teman Sebaya \\ Mayoritas remaja mendapatkan} dukungan dari teman sebaya untuk 
mengonsumsi makanan cepat saji sebanyak 4-27 kali dalam satu bulan. Pada penelitian tersebut, berdasarkan FGD yang dilakukan, ajakan teman sebaya menjadi salah satu faktor yang mempengauhi remaja untuk memilih makanan cepat saji atau fast food dibandingkan dengan makanan lainnya ${ }^{18}$.

Pada penelitian lain, ajakan teman sebaya juga menjadi penyebab tingginya konsumsi makanan cepat saji pada remaja. Padahal remaja tersebut sudah mengetahui bahaya makanan cepat saji bagi kesehatan. Selain itu, remaja lebih senang makan bersama teman-temannya daripada makan di rumah, sehingga dapat menyebabkan remaja memiliki kebiasaan makan yang buruk ${ }^{17}$.

\section{Tempat nyaman untuk berkumpul}

Restoran makanan cepat saji ataupun junk food biasanya menjadi tempat berkumpul bersama keluarga ataupun teman. Tempat makan yang santai dan nyaman, serta tata ruang yang menarik, ditambah dengan adanya wifi gratis menjadi daya tarik tersendiri bagi konsumen untuk makan di restoran cepat saji ${ }^{28}$.

Tempat nyaman yang disediakan oleh restoran cepat saji banyak digunakan oleh pelajar maupun mahasiswa untuk mengerjakan tugas di tempat tersebut. Hal tersebut menyebabkan frekuensi konsumsi makanan cepat saji pada remaja menjadi tinggi. Selain karena tenpat yang nyaman, posisi restoran yang strategis juga mempengaruhi tingginya konsumsi makanan cepat saji pada remaja, seperti lokasi yang dekat dengan sekolah mereka $^{17}$.

Tempat yang nyaman menjadi salah satu daya tarik bagi konsumen untuk makan di restoran makanan cepat saji. Jarak yang dekat maupun jarak yang jauh tidak mempengaruhi responden untuk tidak makan makanan cepat saji karena alasan utama mereka adalah untuk mendapatkan tempat yang nyaman ${ }^{18}$.

\section{Cepat dan praktis \\ Pelayanan yang cepat dan} penyajian yang praktis juga mempengaruhi masyarakat untuk mengonsumsi makanan cepat saji. Bagi mahasiswa, mengonsumsi makanan cepat saji menjadi pilihan karena keterbatasan waktu yang dimiliki ${ }^{10}$.

Selain itu, makanan cepat saji menjadi pilihan orang tua yang memiliki banyak kesibukan. Orang tua saat ini juga banyak yang mengajak anaknya untuk berkumpul bersama keluarga di restoran makanan cepat saji. Makanan di restoran cepat saji selalu tersedia karena dibuat menggunakan mesin, sehingga proses pembuatannya cepat dan terlihat bersih ${ }^{30}$. Alasan mengonsumsi makanan cepat saji adalah karena penyajiannya yang cepat. Pada saat ini, masyarakat menginginkan semua serba cepat. Oleh karena itu, sebagian besar masyarakat khususnya remaja menginginkan semua yang serba cepat, seperti memilih makanan instan, baik pada saat proses penyajian maupun pada saat dimakan. Remaja hanya membutuhkan waktu beberapa menit untuk menunggu makanan yang dipesan datang dan siap dimakan ${ }^{12}$.

\section{Rasa yang enak}

Salah satu alasan sering mengonsumsi makanan cepat saji adalah karena rasa yang enak (Pratiwi, 2018). Remaja yang terbiasa mengonsumsi makanan cepat saji menganggap bahwa makanan cepat saji adalah makanan yang memiliki rasa yang enak, mudah didapat dan dapat menggugah selera makan ${ }^{17}$.

Makanan cepat saji maupun junk food umumnya disukai oleh masyarakat, termasuk remaja karena memiliki rasa 
yang enak. Faktor yang menyebabkan makanan cepat saji memiliki rasa yang enak adalah tingginya kandungan minyak, garam dan gula. Restoran makanan cepat saji pada umumnya berlomba-lomba membuat variasi makanan baru dengan rasa yang enak sehingga sesuai dengan selera masyarakat ${ }^{28}$.

Alasan pertama kali mengonsumsi makanan cepat saji pada remaja di Yogyakarta adalah karena makanan cepat saji memiliki rasa yang enak. Makanan tersebut memiliki rasa yang enak karena kandungan monosodium glutamat (MSG), garam sodium, gula, lemak dan zat adiktif yang menyebabkan kecanduan pada rasa yang enak dan gurih tersebut ${ }^{12}$.

\section{Uang saku}

Pendapatan pada suatu kelompok yang mengalami peningkatan juga akan mempengaruhi perubahan gaya hidup, terutama pada pola makan. Pola makan masyarakat berubah menjadi ke arah yang tidak sehat, seperti makan makanan cepat saji. Pendapatan orang tua juga akan berpengaruh pada uang saku yang diterima remaja. Ketersediaan uang saku yang diterima remaja akan mempengaruhi pola konsumsi makanan cepat saji. Semakin besar uang saku yang dimiliki remaja, maka semakin banyak dan semakin sering remaja mengonsumsi makanan cepat saji ${ }^{14}$.

Mayoritas remaja menggunakan sepertiga dari uang saku mereka setiap bulan untuk membeli dan mengonsumsi makanan cepat saji. Rata-rata uang saku remaja yang duduk dibangku SMA pada penelitian tersebut adalah sebesar $\mathrm{Rp}$ $5.000,00-\operatorname{Rp} 43.000,00^{18}$.

\section{Harga yang murah}

Harga yang murah dan porsi besar yang ditawarkan restoran cepat saji juga berpengaruh terhadap kebiasaan mengonsumsi makanan cepat saji. Selain itu, banyaknya penawaran diskon oleh restoran cepat saji juga meningkatkan keinginan masarakat untuk membeli makanan tersebut ${ }^{28}$. Diskon dan paket hemat yang ditawarkan membuat konsumen, khususnya remaja menjadi semakin tertarik untuk datang dan mengonsumsi makanan cepat saji ${ }^{17}$.

\section{Brand makanan cepat saji}

Brand dari suatu restoran cepat saji dapat mempengaruhi seseorang mengonsumsi makanan cepat saji ini. Remaja cenderung mengonsumsi makanan yang memiliki brand atau merk yang terkenal sebagai ekspresi diri dalam pergaulan dan menjadi ajang bergengsi. Hal yang menjadi trend pada remaja saat ini adalah berfoto di tempat makan dengan brand tersebut untuk ditunjukkan ke teman-teman mereka melalui media sosial. Hal tersebut menunjukkan bahwa mereka telah mengunjungi dan makan di restoran dengan brand tersebut ${ }^{28}$.

\section{Dampak Mengonsumsi Makanan Cepat Saji bagi Kesehatan}

1. Obesitas atau kegemukan

Remaja yang mengonsumsi makanan cepat saji diluar batas wajar dapat berisiko mengalami obesitas atau kegemukan. Remaja yang mengonsumsi makanan cepat saji dengan asupan energi total yang tinggi memiliki risiko sebesar 2,27 kali lebih tinggi mengalami obesitas daripada remaja yang mengonsumsi asupan energi makanan cepat saji yang rendah. Kebiasaan makan yang salah pada anak maupun remaja akan meningkatkan kejadian obesitas, salah satunya adalah kebiasaan makan makanan makanan cepat saji ${ }^{26}$.

Selain itu, konsumsi makanan cepat saji dengan frekuensi yang sering memiliki risiko 2,03 kali lebih besar 
mengalami obesitas dibandingkan dengan remaja yang jarang mengonsumsi makanan cepat saji26.

Remaja yang mengalami obesitas memiliki frekuensi konsumsi makanan cepat saji lebih sering dibandingkan remaja yang tidak mengalami obesitas, perbandingannya yaitu $61,1 \%$ dan $38,9 \%$. Remaja yang sering mengonsumsi makanan cepat saji berisiko 2,47 kali lebih besar mengalami obesitas dibandingkan remaja yang jarang mengonsumsi makanan cepat saji. Berdasarkan wawancara pada penelitian tersebut, remaja yang mengalami obesitas makan di restoran yang menyediakan makanan cepat saji sebanyak 1 sampai 2 kali dalam satu minggu ${ }^{11}$.

Kegemukan yang dialami anakanak maupun remaja dapat disebabkan karena gaya hidup masa kini, seperti mengonsumsi makanan cepat saji atau fast food modern yang mengandung tinggi lemak dan kalori namun memiliki kandungan serat, vitamin, dan mineral yang rendah. Makanan tersebut diantaranya seperti burger, pizza, dan french fries ${ }^{7}$.

Berdasarkan penelitian di Inggris, mengonsumsi makanan cepat saji yang memiliki kadar enegri tinggi menjadi salah satu faktor yang dapat menyebabkan kelebihan berat badan atau obesitas. Makanan cepat saji tidak hanya dijadikan sebagai makanan berat, namun makanan cepat saji juga dijadikan sebagai makanan ringan ${ }^{6}$.

Kegemukan atau obesitas disebabkan karena gizi lebih pada tubuh. Kelebihan energi yang dikonsumsi disimpan dalam jaringan dalam bentuk lemak. Kegemukan merupakan salah satu faktor risiko terjadinya penyakit degeneratif, seperti hipertensi, penyakit diabetes, jantung koroner, hati, dan kantung empedu².
2. Meningkatkan faktor risiko tekanan darah tinggi (hipertensi)

Makanan cepat saji, seperti kentang goreng memiliki rasa yang enak bagi kebanyakan orang. Tanpa disadari, makanan tersebut mengandung garam yang tinggi yang dapat meningkatkan air liur dan sekresi enzim, sehingga meningkatkan keinginan untuk terus makan makanan tersebut. Tingginya kandungan lemak jahat dan natrium mengganggu keseimbangan sodium dan potasium dalam tubuh, sehingga menyebabkan hipertensi ${ }^{13}$.

Kandungan natrium yang tinggi telah diketahui sebagai faktor penyebab tekanan darah tinggi. Natrium diketahui mempengaruhi sistem renin-sngiotensin pada ginjal yang nantinya dapat menyebabkan tekanan darah tinggi ${ }^{3}$.

Penelitian di Amerika menunjukkan bahwa seseorang yang mengonsumsi makanan cepat saji dalam porsi yang besar serta dengan frekuensi 2 sampai 3 kali per minggu, maka dapat mengakibatkan hipertensi ${ }^{16}$.

Penelitian di Yogyakarta juga menunjukkan ada hubungan yang signifikan antara kebiasaan makan makanan cepat saji dengan kejadian hipertensi. Semakin sering kebiasaan makan makanan cepat saji, maka akan memiliki peluang sebesar 0,451 mengalami kejadian hipertensi22.

Hipertensi merupakan salah satu penyakit yang disebabkan karena obesitas. Dengan kata lain, obesitas merupakan faktor risiko dari terjadinya penyakit hipertensi. Terdapat hubungan antara angka kejadian hipertensi dan berat badan yang meningkat secara drastis sesuai dengan peningkatan berat badan. Risiko menderita hipertensi meningkat 1,6 kali pada orang yang overweight, menjadi 3,2 kali pada orang 
yang obesitas kelas 1, serta 3,9-5,5 kali untuk obesitas kelas 2 dan 31 .

\section{Meningkatkan faktor risiko diabetes}

Sering mengonsumsi makanan cepat saji adalah salah satu penyebab utama meningkatnya trend masalah kesehatan, termasuk kejadian diabetes ${ }^{5}$.

Penelitian di Singapura menunjukkan bahwa orang yang mengonsumsi makanan cepat saji khas negara barat dengan frekuensi yang sering memiliki risiko lebih besar menderita diabetes melitus tipe $2^{20}$.

Saat ini telah banyak terjadi bahwa orang-rang masa kini tidak dapat melawan kebiasaan konsumsi makanan cepat saji yang dapat memberikan efek bagi kesehatan masyarakat. Sering mengonsumsi makanan cepat saji memiliki efek yang menyebabkan peningkatan gangguan metabolisme, termasuk kegemukan, resistensi insulin, diabetes tipe 2, serta gangguan kardiovaskular5.

Salah satu penyebab diabetes adalah obesitas. Sedangkan obesitas merupakan salah satu akibat dari makan makanan cepat saji yang pada umumnya memiliki kandungan gizi yang rendah. Risiko menderita diabetes melitus akan meningkat secara linier sesuai dengan peningkatan indeks massa tubuh (IMT). Orang dengan overweight atau IMT diatas rata-rata akan menigkatkan angka kejadian diabetes melitus sebesar 3-4 kali dibangingkan dengan orang dengan IMT yang normal ${ }^{1}$.

\section{Meningkatkan faktor risiko kanker}

Konsumsi makanan cepat saji dapat meningkatkan risiko kanker, seperti kanker pada organ sistem pencernaan. Studi di Eropa menyebutkan bahwa konsumsi makanan cepat saji yang terlalu sering dapat meningkatkan risiko kanker kolorektal. Hal ini karena makanan cepat saji kuang mengandung serat, namun tinggi gula dan lemak. Selain itu, penelitian lain menunjukkan bahwa pria yang terlalu sering makan makanan yang digoreng lebih dari dua kali dalam satu bulan telah menunjukkan peningkatan risiko kanker prostat ${ }^{13}$.

Kebiasaan mengonsumsi makanan cepat saji merupakan faktor risiko kejadian FAM atau fibroadenoma mammae yang merupakan tumor jinak. Penderita FAM tersebut memiliki risiko 2 kali lebih besar menderita penyakit kanker payudara di kemudian hari ${ }^{23}$.

Makanan cepat saji yang identik dengan daging yang dimasak dengan temperatur tinggi akan membentuk zatzat karsinogenik. Zat tersebut berpotensi membentuk tumor payudara dan akan meningkatkan risiko kanker ${ }^{24}$.

5. Meningkatkan faktor risiko penyakit jantung

Penyakit jantung menjadi salah satu penyebab kematian yang menakutkan. Ketersediaan makanan cepat saji yang tinggi dikaitkan dengan kematian dan penyakit jantung koroner akut, serta kelebihan berat badan dan obesitas yang tinggi.

Salah satu penyebab terjadinya penyakit jantung adalah obesitas yang dialami seseorang. Hal ini karena obesitas meningkatkan risiko terjadinya penyakit jantung. Seseorang yang memiliki berat badan diatas rata-rata atau obesitas akan mengalami risiko penurunan fungsi jantung, termasuk fungsi jantung menjadi tidak normal ${ }^{1}$.

\section{Meningkatkan faktor risiko stroke \\ Pola makan yang salah seperti} makan makanan cepat saji dapat memicu terjadinya stroke pada usia muda. Hal ini disebabkan karena kandungan kolesterol yang tinggi. Kolesterol tidak baik bagi kesehatan, yaitu apabila terjadi 
penyumbatan pembuluh darah. Apabila mengenai pembuluh darah otak, maka akan mengakibatkan stroke ${ }^{1}$.

Kasus stroke di negara maju meningkat akibat kejadian kegemukan dan semakin banyaknya konsumsi makanan cepat saji pada masyarakat. Peningkatan jumlah penderita stroke di Indonesia juga identik dengan kegemukan akibat pola makan makanan yang mengandung tinggi lemak atau kolesterol $^{1}$.

\section{DAFTAR RUJUKAN}

Makanan cepat saji merupakan makanan yang kurang baik bagi remaja apabila dikonsumsi terlalu sering. Banyaknya remaja yang mengonsumsi makanan cepat saji disebabkan karena beberapa faktor, diantaranya adalah pengetahuan, pengaruh teman sebaya, tempat nyaman untuk berkumpul, cepat dan praktis, uang saku, hargayang murah, dan brand dari makanan cepat saji. Apabila makanan cepat saji dikonsumsi secara berlebihan, maka akan berdampak pada kesehatan remaja. masalah kesehatan tersebut adalah obesitas, meningkatkan faktor risiko hipertensi, diabetes, kanker, penyakit jantung, dan stroke.

\section{DAFTAR RUJUKAN}

[1] Adriani, M. \& Wirjatmadi, B. 2012. Peranan Gizi dalam Siklus Kehidupan. Jakarta : Prenamedia Group.

[2] Almatsier, S. 2009. Prinsip Dasar Ilmu Gizi. Jakarta : PT Gramedia Pustaka Utama.

[3] Arya, G. \& Mishra, S. 2013. Effects of Junk Food \& Beverages on Adolescent's Health - A Review
Article. Journal of Nursing and Health Science Vol. 1 No. 6.

[4] Bahadoran, Z., Mirmiran, P., Esfahani, F.H. \& Azizi, F. 2013. Fast Food Consumption and The Risk of Metabolic Syndrome After 3-years of Follow-up : Tehran Lipid and Glucose Study. European Journal of Clinical Nutrition.

[5] Bahadoran, Z., Mirmiran, P. \& Azizi, F. 2015. Fast Food Pattern and Cardiometabolic Disorders : A Review of Current Studies. Health Promotion Perspective Vol. 5 No. 4.

[6] Barasi, M.E. 2007. Nutrition At A Glance. Blackwell Publishing.

[7] Damopolii, W., Mayulu, N. \& Masi, G. 2013. Hubungan Konsumsi Fastfood dengan Kejadian Obesitas pada Anak $S D$ di Kota Manado. Ejournal Keperawatan Universitas Sam Ratulangi Manado Vol. 1 No. 1.

[8] Depkes, Poltekkes. 2010. Kesehatan Remaja : Problem dan Solusinya. Jakarta : Penerbit Salemba Medika.

[9] Goon, S., Bipasha, M.S. \& Islam, Md. 2014. Fast Food Consumption and Obesity Risk Among University Students of Bangladesh. Europan Journal of Preventive Medicine Vol. 2 No.6.

[10] Khairiyah, E.L. 2016. Pola Makan Mahasiswa Fakultas Kedokteran dan Ilmu Kesehatan (FKIK) UIN Syarif Hidayatullah Jakarta Tahun 2016. Skripsi. Universitas Islam Negeri Syarif Hidayatullah Jakarta.

[11] Kurdanti, W., Suryani, I., Syamsiatun, N.H., Siwi, L.P., Aditysnti, M.M., Mustikaningsih, D. \& Sholihah, K.I. 2015. Faktor-Faktor yang Mrmprngaruhi Kejadian Obesitas pada Remaja. Jurnal Gizi Klinik Indonesia Vol. 11 No. 04.

[12] Lestari, D. 2012. Perilaku Konsumsi Junk Food pada Siswa di SMA Negeri 1 Depok Sleman Yogyakarta. Naskah 
Publikasi Sekolah Tinggi Ilmu Keperawatan 'Aisyiyah Yogyakarta.

[13] Marwan, M.R., 2017. Bahaya Makan Terlalu Banyak Makanan Restoran Cepat Saji. <Tersedia di : http://news.gunadarma.ac.id/2017 /05/bahaya-makan-terlalu-banyakmakanan-restoran-cepat-saji/> [diakses pada 7 Desember 2018].

[14] Masthalina, H., Suhaema, Mizwar, M. 2013. Ketersediaan Uang Saku, Aktivitas dan Pengetahuan Remaja Berhubungan dengan Pola Konsumsi Fast Food di SMAN 1 Mataram. Jurnal Media Gizi Pangan.

[15] Menteri Kesehatan Republik Indonesia. 2014.

[16] Mihrete, K. 2012. Association Between Consumption and Obesity and High Blood Pressure among Office Workers. Dissertation. Walden University.

[17] Mustikaningsih, D., Hartini, T.N.S. \& Syamsiatun, N.H. 2015. Persepsi tentang Fast Food dan Frekuensi Konsumsi Fast Food sebagai Faktor Risiko Terjadinya Obesitas pada Remaja di Yogyakarta. Jurnal Nutrisia Vo. 17 No. 2.

[18] Nusa, A.F.A. \& Adi, A.C. 2013. Hubungan Faktor Perilaku, Frekuensi Konsumsi Fast Food, Diet dan Genetik dengan Tingkat Kelebihan Berat Badan. Media Gizi Indonesia Vol. 9 No. 1.

[19] Octavia, L.I., 2018. Dampak Konsumsi Junk Food Jangka Panjang. $<$ Tersedia di http://www.yankes.kemkes.go.id/r ead-dampak-konsumsi-junk-foodjangka-panjang-3958.html> [diakses pada 4 Desember 2018].

[20] Odegaard, A.O., Koh, W.P., Yuan, J.M., Gross, M.D. \& Pereira, M.A. 2012. Western-Style Fast Food Intake and Cardiometabolic Risk in an Estern Country. Circulation 126(2).
[21] Peraturan Menteri Kesehatan Nomor 25 Tahun 2014 Tentang Upaya Kesehatan Anak. Jakarta.

[22] Pratiwi, H., Sety, L.O.M. \& Tina, L. 2018. Analisis Faktor Risiko Kejadian Penyakit Fibroadenoma Mammae (FAM) di Rumah Sakit Umum Daerah Bahteramas Provinsi Sulawesi Tenggara Tahun 2017. Jurnal Ilmiah Mahasiswa Kesehatan Masyarakat Vol. 3 No. 2.

[23] Pratiwi, M.D. 2010. Hubungan Pola Makan Fast Food dengan Kejadian Hipertensi pada Usia Produktif di Dusun Tegal Ngijon Sumber Agung Moyudan Sleman Yogyakarta. Naskah Publikasi Sekolah Tinggi Ilmu Keperawatan 'Aisyiyah Yogyakarta.

[24] Putra, S.R. 2015. Buku Lengkap Kanker Payudara. Yogyakarta : Laksana.

[25] Purohit, G., Shah, T. \& Harsoda, J..M. 2015. Prevalence of Obesity in Medical Students and Its Correlation with Cardiovascular Risk Factors : Emergency Alarm for Today?. Kathmandu University Mecidal Journal Vol. 13 No. 4.

[26] Rafiony, A., Purba, M.B. \& Pramantara, I.D.P. 2015. Konsumsi Fast Food dan Soft Drink sebagai Faktor Risiko Obesitas pada Remaja. Jurnal Gizi Klinik Indonesia Vol. 11 No. 04.

[27] Sari, R. W. 2008. Dangerous Junk Food: Bahaya Makanan Cepat Saji dan Gaya Hidup Sehat. Yogyakarta : Penerbit 02.

[28] Septiana, P., Nugroho, F.A. \& Wilujeng, C.S. 2018. Konsumsi Junk Food dan Serat pada Remaja Putri Overweight dan Obesitas yang Indekos. Jurnal Kedokteran Brawijaya Vo. 30 No.1.

[29] Semiun, Y. 2006. Kesehatan Mental 1. Yogyakarta : Penerbit Kanisius. 
[30] Setyawati, V.A.V. \& Rimawati. 2016. Pola Konsumsi Fast Food dan Serat sebagai Faktor Gizi Lebih pada Remaja. Unnes Journal of Public Health Vol. 5 No.3.

[31] Shah, T., Purohit, G., Nair, S.P., Patel, B., Rawal, Y. \& Shah, R.M. 2014. Assessment of Obesity, Overweight and Its Association with The Fast Food Consumption in Medical Students. Journal of Clinical and Diagnostic Research. Vol. 8 No. 5.

[32] World Health Organization. 2014. Health for The World's Adolescents : A Second Chance in The Second Decade. Geneva : WHO Document Production Services. 